Original Article

\title{
ADAPTOGENIC ACTIVE COMPONENT FROM MYXOPYRUM SMILACIFOLIUM
}

\author{
E. N. SIJU1, JOLLY SAMU1* ${ }^{*}$, M. MINIL1, G. R. RAJALAKSHMI²
}

${ }^{1}$ Department of Pharmacology, Academy of Pharmaceutical Science, Pariyaram Medical College, Kannur 670503, Kerala, India, ${ }^{2}$ College of Pharmaceutical Sciences, Government Medical College, Kozhikode 673008, Kerala, India

Email: jollyssamu@gmail.com

Received: 24 Sep 2016, Revised and Accepted: 25 Nov 2016

\section{ABSTRACT}

Objective: The present study was designed to investigate the adaptogenic active component from the extracts of Myxopyrum smilacifolium.

Methods: The plant extract was undergone different separation technique viz precloumn, HPTLC, etc for isolation of pure compound. Thereafter the pure compound was subjected to IR, NMR, LC-MS for structural elucidation.

Results: Chemical characterization of the adaptogenic fraction by spectroscopy showed iridoid glycoside as major constituents.

Conclusion: The present study showed iridoid glycoside is considered the adaptogenic agents of Myxopyrum smilacifolium Blume.

Keywords: Myxopyrum smilacifolium, HPTLC, LCMS, NMR, FTIR

(C) 2016 The Authors. Published by Innovare Academic Sciences Pvt Ltd. This is an open access article under the CC BY license (http://creativecommons.org/licenses/by/4.0/] DOI: http://dx.doi.org/10.22159/ijcpr.2017v9i1.16630

\section{INTRODUCTION}

The plant kingdom is a rich source of biologically active agents, revealing various types of pharmacological activities. Herbal formulations have been used for many years globally not only as therapeutic but also as prophylactic and health promotive agents. The universal role of plants in the treatment of disease is exemplified by their employment in all the major systems of medicine irrespective of the underlying philosophical premise. The use of modern isolation techniques and pharmacological testing procedures means that new plant drugs usually find their way into medicine as purified substances rather than in the form of preparations [1]. The medicinal plant contains some organic compounds which produce definite physiological action on the human body and these bioactive substances include tannins, alkaloids, carbohydrates, terpenoids, steroids and flavonoids [2]. Phytochemical constituents are the basic source for the establishment of several pharmaceutical industries.

Myxopyrum smilacifolium Blume (Family-Oleaceae) is an important medicinal plant widely used in indigenous system of medicine in India. The leaves are astringent, acrid, sweet, thermogenic, anodyne, febrifuge and tonic. They are useful in vitiated conditions of kapha, vata, cough, asthma, rheumatism, nostalgia, consumption, fever, otopathy, neuropathy and cuts and wounds [3, 4]. Earlier the plant has been studied for its antimicrobial [4], antioxidant, wound healing activity [5].

In the present study, the phytochemical constituents have been isolated from the leaves of Myxopyrum smilacifolium Blume.

\section{MATERIALS AND METHODS}

\section{Collection of plant material}

The leaves of Myxopyrum Smilacifolium Blume was collected from Agricultural University, Odakkali, Ernakulam, Kerala (India) in the month of September 2013 and authenticated by Dr. Radhika, Govt Ayurvedic College Pariyaram, Kannur. The leaves were dried in the shade at room temperature. The dried leaves were pulverised in a mechanical grinder to obtain a coarse powder.

\section{Extraction and isolation}

The dried and powdered materials of the above were subjected to extraction in soxhlet apparatus, using a different solvent with increasing polarity ie, petroleum ether, chloroform, methanol and ethanol. Evaporation of solvent from the extracts was done by rotary vaccum evaporator. A sticky mass was obtained after evaporation of this solvent. The extracts were stored at $10^{\circ} \mathrm{C}$ till further use. The plant extract was undergone different separation technique viz precloumn, HPTLC, etc for isolation of pure compound. Thereafter the pure compound was subjected to IR, NMR, LC-MS for structural elucidation.

\section{Trim Hill colour Test ${ }^{6}$}

Fresh Extract (1 gm), test tube with $5 \mathrm{ml} 1 \%$ aqueous $\mathrm{HCl}$. After 3-6 $\mathrm{hr}, 0.1 \mathrm{ml}$ of the macerate is decanted into another tube containing 1 $\mathrm{ml}$ of the Trim Hill reagent $\left(10 \mathrm{ml}\right.$ acetic acid, $1 \mathrm{ml}$ of $0.2 \% \mathrm{CuSO}_{4}$, $5 \mathrm{H}_{2} \mathrm{O}$ in water and $0.5 \mathrm{ml}$ con. $\mathrm{HCl}$ ). The tube is heated for a short time in a flame; a colour is produced if certain iridoid are present.

\section{RESULTS}

Ethanol extract of Myxopyrum smilacifolium showed a positive result for the Trim Hill colour Test (test for iridoid glycoside). From LC-MS data, its molecular formula was determined as $\mathrm{C}_{14} \mathrm{H}_{16} \mathrm{O}_{8}$ (aglycone) and $\mathrm{C}_{12} \mathrm{H}_{16} \mathrm{O}_{8}$ (fragment). The UV spectrum of the compound displayed an absorption maximum at $239 \mathrm{~nm}$, which is the characteristic of an iridoid skeleton, and FT-IR bands at 3397 and $1725 \mathrm{~cm}^{-1}$, which indicated the presence of hydroxyl and carbonyl functionalities, respectively.

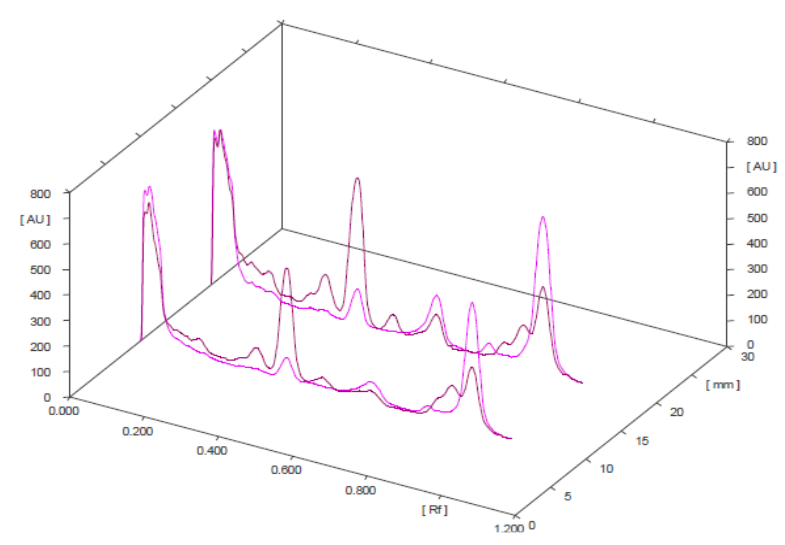

Fig. 1: It shows HPTLC of iridoid glycoside 


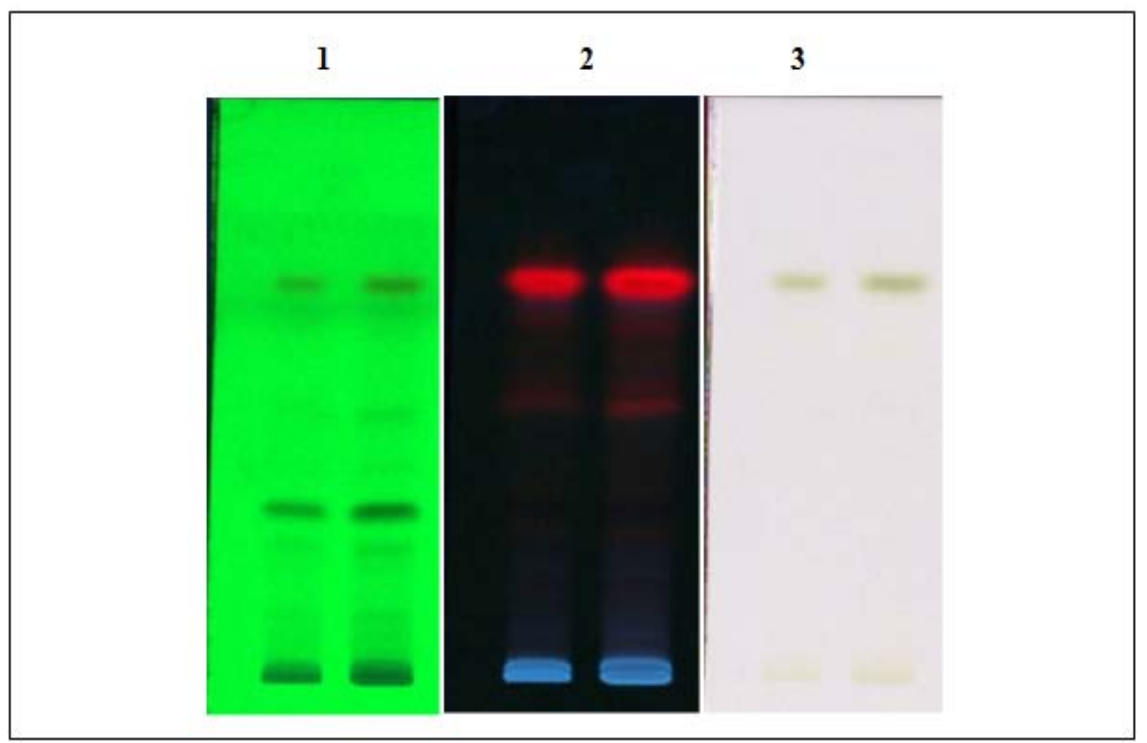

Fig. 2: HPTLC profiles of iridoid glycoside from the ethanol extract of Myxopyrum smilacifolium Blume. Illuminations type: 1. 254 nm remission, $2.366 \mathrm{~nm}$ remission, 3 . white remission

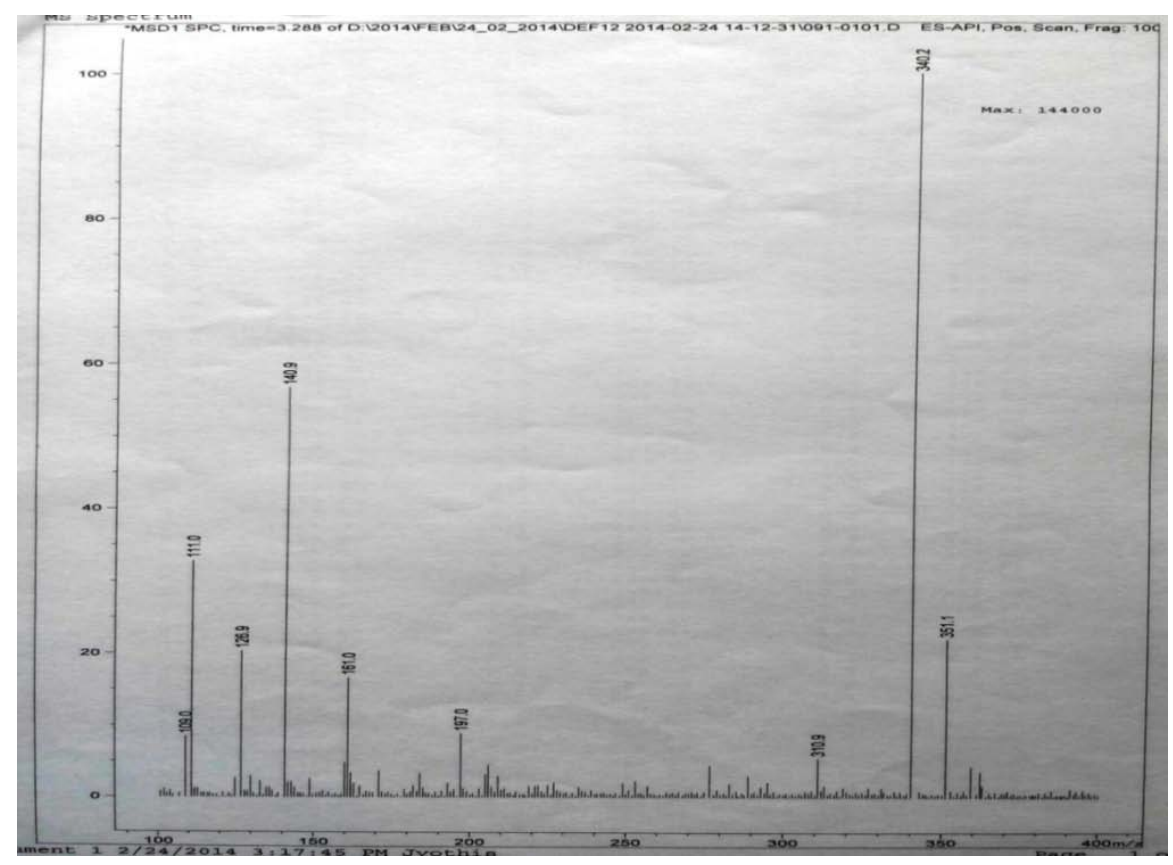

Fig. 3: It shows LC-MS of iridoid nucleus

Table 1: It shows LC-MS details of Iridoid nucleus

\begin{tabular}{llll}
\hline S. No. & Mol. formula & M. W & $\mathbf{m} / \mathbf{z}$ \\
\hline 1. & $\mathrm{C}_{14} \mathrm{H}_{16} \mathrm{O}_{8}$ (Aglycone) & 312 & $311(\mathrm{M}-1)$ \\
2. & $\mathrm{C}_{12} \mathrm{H}_{16} \mathrm{O}_{8}$ (Fragment) & 288 & $288(\mathrm{M}+)$ \\
\hline
\end{tabular}

Table 2: It shows FTIR details of iridoid glycosides

\begin{tabular}{lll}
\hline S. No. & Functional group & Wave number (in $\mathbf{~ c m}^{-1}$ ) \\
\hline 1. & O-H stretching & 3397 \\
2. & Aliphatic C-H Stretching & 2926 \\
3. & C=O Stretching & 1725 \\
4. & C-C Stretching & 1642 \\
5. & C=C Stretching & 1375 \\
6. & C-O-C Bending & 1073 \\
\hline
\end{tabular}




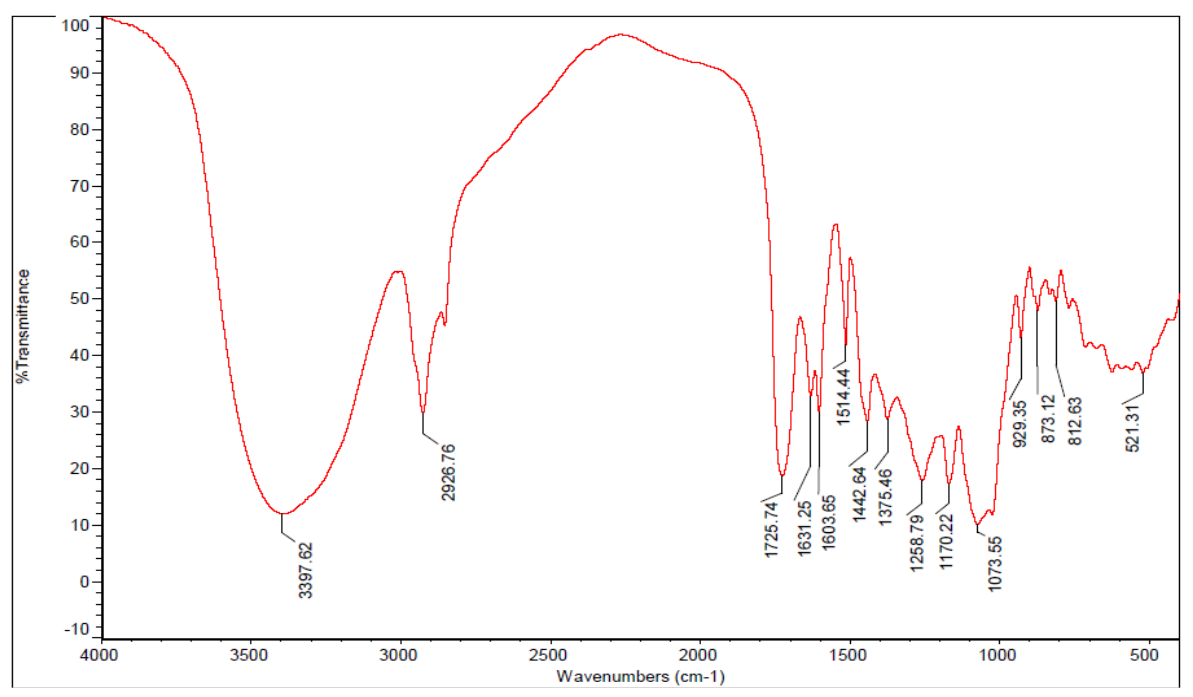

Fig. 4: It shows FTIR of iridoid glycoside

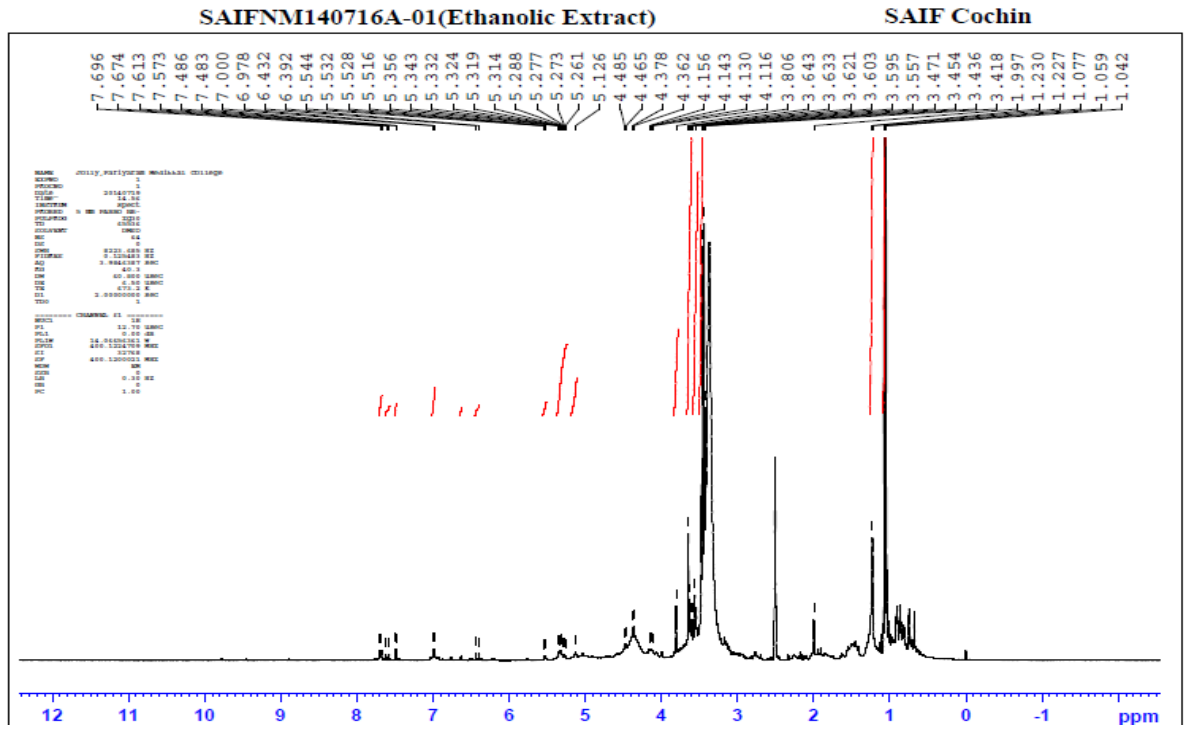

Fig. 5: It shows NMR of iridoid glycoside

Table 3: It shows NMR details of iridoid glycoside

\begin{tabular}{|c|c|c|}
\hline S. No. & $\delta$ value (ppm) & Proton \\
\hline 1. & 5.126 & $(s, \mathrm{RC}=\mathrm{CH}, 1 \mathrm{H})$ \\
\hline 2. & 3.454 & $\left(s, \mathrm{COOCH}_{3}, 3 \mathrm{H}\right)$ \\
\hline 3. & 1.042 & $\left(t, \mathrm{R}_{3} \mathrm{CH}, 1 \mathrm{H}\right)$ \\
\hline 4. & 3.0471 & $(t, \mathrm{HC}-\mathrm{OR}, 1 \mathrm{H})$ \\
\hline 5. & 3.418 & $(s, \mathrm{R}-\mathrm{C}=\mathrm{CH}, 1 \mathrm{H})$ \\
\hline 6. & 3.621 & $(t, \mathbf{H C}-\mathrm{OH}, 1 \mathrm{H})$ \\
\hline 7. & 3.806 & $(s, \mathrm{R}-\mathrm{OH}, 1 \mathrm{H})$ \\
\hline 8. & 1.077 & $\left(t, \mathrm{R}_{3}-\mathrm{CH}, 1 \mathrm{H}\right)$ \\
\hline 9. & 3.436 & $\left(s, \mathrm{COOCH}_{3}, 3 \mathrm{H}\right)$ \\
\hline 10. & 1.059 & $\left(t, \mathrm{R}_{3}-\mathrm{CH}, 1 \mathrm{H}\right)$ \\
\hline S. No. & $\delta$ value $(\mathrm{ppm})$ & Proton \\
\hline 11. & 3.557 & $(d, \mathrm{RO}-\mathrm{CH}, 1 \mathrm{H})$ \\
\hline 12. & 3.643 & $(d, \mathrm{CH}-\mathrm{OR}, 1 \mathrm{H})$ \\
\hline 13. & 3.621 & $(t, \mathrm{CH}-\mathrm{OR}, 1 \mathrm{H})$ \\
\hline 14. & 4.116 & $(s, \mathrm{RO}-\mathrm{H}, 1 \mathrm{H})$ \\
\hline 15. & 3.603 & $(t, \mathrm{CH}-\mathrm{OR}, 1 \mathrm{H})$ \\
\hline 16. & 4.130 & $(s, \mathrm{R}-\mathrm{OH}, 1 \mathrm{H})$ \\
\hline 17. & 4.143 & $(s, \mathrm{R}-\mathrm{OH}, 1 \mathrm{H})$ \\
\hline 18. & 3.595 & $(t, \mathrm{C}-\mathrm{OR} .1 \mathrm{H})$ \\
\hline 19. & 3.633 & $(q, \mathrm{CH}-\mathrm{OR}, 1 \mathrm{H})$ \\
\hline 20. & 4.156 & $\left(s, \mathrm{CH}_{2}-\mathrm{OR}, 2 \mathrm{H}\right)$ \\
\hline
\end{tabular}




\section{DISCUSSION}

The phytochemical investigation was performed with Myxopyrum smilacifolium Blume. This showed the presence of an iridoide nucleus. Their structure was established on the basis of spectroscopic evidence, and the proposed structure is given below. Based on the physical and spectroscopic examination the compound may be an iridoid glycoside.

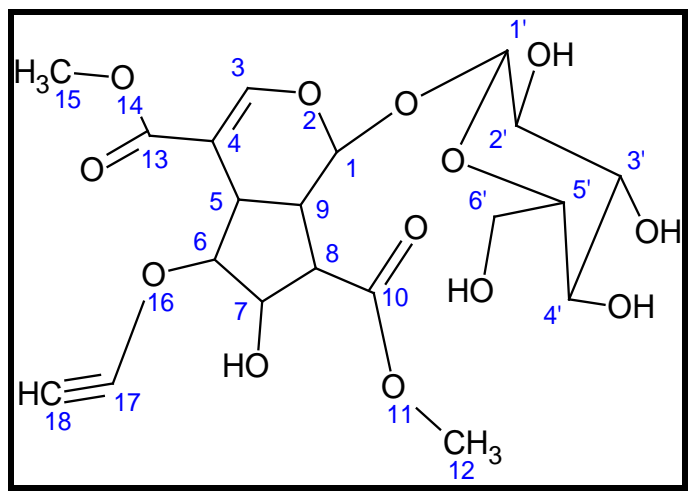

Iridoids are powerful phytochemicals produced by plants as a selfdefense mechanism. Iridoids represent a large and still expanding group of cyclopenta [c] pyran monoterpenoids found in a number of folk medicinal plants used as a bitter tonic, sedatives, hypotensives, antipyretics, cough medicines, remedies for wounds and skin disorder. They are also adaptive, which means they can adapt to an environment to safety benefit and function of biological systems. Iridoids have been scientifically proven to eliminate harmful free radicals, maintain cholesterol at already existing normal levels, increase energy, promote heart health, boost the immune system, support DNA and support healthy brain activity. Iridoids have the following properties when consumed as part of a healthy lifestyle nutritional supplement, that support the immune system, protect the liver, DNA, promote joint health, increase energy and endurance, help to maintain healthy HDL cholesterol within already existing normal levels [6-8].

\section{CONCLUSION}

In the present investigation, iridoid glycoside has been identified from the ethanolic extract of Myxopyrum smilacifolium by HPTLC LCMS, FTIR, and NMR. Analytical studies showed the presence of iridoid glycoside; may be the reason for its adaptogenic activity.
However isolation of the individual phytochemical constituents and subjecting to biological activity will definitely give fruitful results. Based on various pharmacological activities observed, most iridoid can be taken on account of an adaptogenic compound that exhibits non-specific resistance against pathologic/abnormal health condition. It could be concluded that Myxopyrum smilacifolium contains mainly adaptogenic compounds.

\section{ABBREVIATION}

FT-IR-Fourier transform infra-red, HCl-Hydrochloric acid, HPTLCHigh performance thin layer chromatography, NMR-Nuclear Magnetic Resonance.

\section{CONFLICT OF INTERESTS}

\section{Declared none}

\section{REFERENCES}

1. Evan WC. Trease and Evans Pharmacognosy. 14th ed. India: Harcourt Brace and company; 1998. p. 138-46, 194.

2. Savithramma N, Linga Rao M. Phytochemical screening of Thespesia populnea Sol. and Tridax procumbens L. J Chem Pharm Res 2011;3 Suppl 5:28-34.

3. Varier PS. Indian medical plants: a compendium of 500 species. Vol. 4. Madras: Orient Longman Limited; 1995. p. 98.

4. Sundharmini D, Ashalatha S Nair. Antimicrobial activity of triterpenoid fractions from Myxopyrum smilacifolium blume. Ethnobotanical Leaflets 2008;12:912-5.

5. Gopalakrishnan S, Rajameena R. Wound healing activity of the Ethanol extract of the leaves of Myxopyrum serratulum A. W. Hill in Rats. Int J Pharm Sci Rev 2013;22 Suppl 1:143-7.

6. Trim, Hill, Weiffering JH. Accubinating glucoside (Psuedoinikane) and verwandle heteroside Ale. systematische. Phytochemistry; 1998. p. 103-4.

7. Melanie Alfred. A Reference book for the biological activity of the constituents of Morinda citrifolia, 2ed. Australia: M and R Naturopathic Clinic; 2012. p. 18-20.

8. Provo, Utah. International Iridoid Research Symposium International Iridoid Research Council; 2010. p. 3-6.

9. Biren NS, Pankaj B Patel, Ankit BP, Dikshit CM. Rehmannia glutinosa-A Phyto-pharmacological review. Pharmacol Online 2010;1:737-53.

\section{How to cite this article}

- EN Siju, Jolly Samu, M Minil, GR Rajalakshmi. Adaptogenic active component from Myxopyrum smilacifolium. Int J Curr Pharm Res 2017;9(1):110-113. 